\title{
Salivary biomarkers of cellular damage and oxidative stress following of lower third molar surgical removal
}

Biomarcadores salivares de dano celular e estresse oxidativo após a remoção cirúrgica do terceiro molar inferior Biomarcadores salivales de daño celular y estrés oxidativo después de la extracción quirúrgica del tercer molar inferior

Layani Bertaglia DIAS ${ }^{1}$

Thaline Teixeira TONZAR ${ }^{1}$

Damaris Raíssa dos SANTOS ${ }^{1,3}$

Rayne Oliveira SOUZA ${ }^{1}$

Tayná Buffulin RIBAS ${ }^{1}$

Leonardo de Freitas SILVA ${ }^{2}$

Erik Neiva Ribeiro de Carvalho REIS ${ }^{2}$

Daniela PONZONI ${ }^{2}$

Rita Cássia Menegati DORNELLES ${ }^{\mathbf{1 , 3}}$

Ana Cláudia de Melo Stevanato NAKAMUNE ${ }^{1,3}$

Antonio Hernandes CHAVES-NETO ${ }^{\mathbf{1 , 3}}$

Department of Basic Sciences, São Paulo State University (Unesp), School of Dentistry, Araçatuba, 16015-050 Araçatuba - SP, Brazil.

${ }^{2}$ Department of Surgery and Integrated Clinic, São Paulo State University (Unesp), School of Dentistry, Araçatuba, 16015-050 Araçatuba - SP, Brazil.

${ }^{3}$ Programa Multicêntrico de Pós-Graduação em Ciências Fisiológicas - SBFis, São Paulo State University (Unesp),

School of Dentistry, Araçatuba, 16015-050 Araçatuba - SP, Brazil.

\section{Abstract}

Background: The aims of this study were the temporal analysis of salivary biomarkers of cellular damage and oxidative stress following of lower third molar surgical removal from healthy patient and without postoperative complications. Material and Methods: Three whole unstimulated saliva samples were collected from each of 17 patients ( 8 men, 9 women) before surgery, 1 and 7 days after lower third molar surgical removal using the expectoration (or 'spit') method. Salivary flow rate (SFR), $\mathrm{pH}$, buffer capacity (BC) were measured, immediately after collection. The samples were centrifuged and the supernatants were stored in aliquots at $-80^{\circ} \mathrm{C}$ until analysis. Salivary thiobarbituric reacting substances (TBARs), total antioxidant capacity (TAC), haemoglobin (Hb), total protein (TP), uric acid (UA), acid phosphatase (ACP), tartrate-resistant acid phosphatase (TRAP), alkaline phosphatase (ALP), aspartate aminotransferase (AST), alanine aminotransferase (ALT), and lactate dehydrogenase (LDH) were measured by spectrophotometric method. Results: There were no significant differences between pre- and post-surgical SFR, pH, BC, or TP. One day after extraction were detected a significant increases in Hb, TBARs, ACP, TRAP, ALP, AST, ALT, and LDH activities, and decreases of UA and TAC levels were observed. Seven days after extraction, only AST (higher) remained increased compared to pre-surgical levels. Conclusions: The surgical removal of impacted lower third molars increases salivary biomarkers of cellular damage and oxidative stress, and decreases the TAC in the early postoperative. Considering these issues, our data open new perspectives of a possible use of these parameters as biomarkers for screening and monitoring of patients vulnerable to the development of postoperative complications.

Descriptors: Saliva; Biomarkers; Oral Surgical Procedures; Oxidative Stress; Enzymes; Thiobarbituric Acid Reactive Substances.

\section{Resumo}

Justificativa: O objetivo deste estudo foi a análise temporal dos biomarcadores salivares de dano celular e estresse oxidativo após a remoção cirúrgica do terceiro molar inferior de paciente saudável e sem complicações pós-operatórias. Material e Método: Três amostras de saliva total não estimulada foram coletadas de cada um dos 17 pacientes (8 homens, 9 mulheres) antes da cirurgia, 1 e 7 dias após a remoção cirúrgica do terceiro molar inferior usando o método da expectoração. A taxa de fluxo salivar (TFS), pH, capacidade tampão (CT) foram medidos, imediatamente após a coleta. As amostras foram centrifugadas e os sobrenadantes foram armazenados em alíquotas a $-80{ }^{\circ} \mathrm{C}$ até a análise. Substâncias reativas com o ácido tiobarbitúrico (SRAT), capacidade antioxidante total (CAT), hemoglobina $(\mathrm{Hb})$, proteína total (PT), ácido úrico (AU), fosfatase ácida (FA), fosfatase ácida resistente ao tartarato (FART), fosfatase alcalina (FAI), aspartato aminotransferase (AST), alanina aminotransferase (ALT) e lactato desidrogenase (LDH) foram medidos por métodos espectrofotométricos nas amostras de saliva. Resultados: Não houve diferenças significantes entre TFS, pH, BC e TP comparando-se as amostras coletadas no pré e pós-cirúrgico. Um dia após a extração do terceiro molar inferior, foram observados aumentos significantes nos parâmetros Hb, SRAT, FA, FART, FAl, AST, ALT e LDH, e reduções nos níveis de AU e CAT. Sete dias após a extração, apenas AST (maior) permaneceu aumentado em comparação aos níveis pré-cirúrgicos. Conclusão: A remoção cirúrgica dos terceiros molares inferiores impactados aumenta os biomarcadores salivares de dano celular e estresse oxidativo e diminui a CAT no pós-operatório precoce. Considerando essas questões, nossos dados abrem novas perspectivas de um possível uso desses parâmetros como biomarcadores para triagem e monitoramento de pacientes vulneráveis ao desenvolvimento de complicações pós-operatórias.

Descritores: Saliva; Biomarcadores; Cirurgia Bucal; Estresse Oxidativo; Enzimas; Substâncias Reativas com Ácido Tiobarbitúrico.

\section{Resumen}

Antecedentes: El objetivo de este estudio fue el análisis temporal de biomarcadores salivales de daño celular y estrés oxidativo después de la extracción quirúrgica del tercer molar inferior de un paciente sano sin complicaciones postoperatorias. Material y Métodos: Se recogieron tres muestras de saliva total no estimulada de cada uno de los 17 pacientes ( 8 hombres, 9 mujeres) antes de la cirugía, 1 y 7 días después de la extracción quirúrgica del tercer molar inferior utilizando el método del esputo. La velocidad de flujo salival (VFS), pH, capacidad de amortiguación (CA) se midieron inmediatamente después de la recolección. Las muestras se centrifugaron y los sobrenadantes se almacenaron en alícuotas a $-80^{\circ} \mathrm{C}$ hasta el análisis. Sustancias reactivas al ácido tiobarbitúrico (SRAT), capacidad antioxidante total (CAT), hemoglobina (Hb), proteína totales (PT), ácido úrico (AU), fosfatasa ácida (FA), fosfatasa ácida tartratorresistente (FATR), fosfatasa alcalina (FAl), aspartato aminotransferasa (AST), alanina aminotransferasa (ALT) y la lactato deshidrogenasa (LDH) se midieron por el método espectrofotométrico en muestras de saliva. Resultados: No hubo diferencias significativas entre VFS, pH, CA y PT comparando las muestras recolectadas antes y después de la cirugía. Un día después de la extracción del tercer molar inferior, se observaron aumentos significativos en los parámetros Hb, SRAT, FA, FATR, FAl, AST, ALT y LDH, y reducciones en los niveles de AU y CAT. Siete días después de la extracción, solo AST (mayor) permaneció aumentado en comparación con los niveles preoperatorios. Conclusiones: La extracción quirúrgica de los terceros molares inferiores impactados aumenta los biomarcadores salivales del daño celular y el estrés oxidativo y disminuye la CAT en el postoperatorio temprano. Teniendo en cuenta estos problemas, nuestros datos abren nuevas perspectivas para un posible uso de estos parámetros como biomarcadores para la detección y el seguimiento de pacientes vulnerables al desarrollo de complicaciones postoperatorias.

Descriptores: Saliva; Biomarcadores; Cirugía Bucal; Estrés Oxidativo; Enzimas; Sustancias Reactivas al Ácido Tiobarbitúrico.

\section{INTRODUCTION}

The surgical removal of impacted lower third molars is one of the most common oral surgery. This surgical procedure can prevent clinical symptoms such as pericoronitis and oral malodor, however, it also may be affects patient's quality of life due various postoperative side effects and/or complication, for example, pain, bleeding, variable swelling, trismus, alveolitis, hygiene and food 
difficulties $^{1}$. Its postoperative recovery process generally takes approximately 7 days and concurrently initiates the socket healing, a complex that involves a coordinated cascade of events that include inflammatory, proliferative, and modelling/remodelling phases ${ }^{2}$. In this context, the saliva has proven to be necessary in the early stages of post-tooth extraction wound healing for optimal healing, as it was found to modulate the expression and activity of inflammatory mediators in alveolar bone tissue repair at the studied time points ${ }^{3,4}$.

Saliva is considered a diagnostic tool capable of providing molecular biomarkers of various oral and systemic diseases ${ }^{5}$. During the inflammatory phase of alveolar wound healing, immunobiologically active substances regulate the cellular movement and infiltration necessary for tissue repair ${ }^{4}$. Growth factors, enzymes, cytokines, and chemokines produced by the stromal, epithelial, and inflammatory cells that accumulate in the wound space during the inflammatory phase, can be released into the oral cavity and influence the composition and function of saliva. The characterization of theses salivary biochemical changes occurring during the early phase of alveolar wound healing could provide biomarkers molecular for prevention, monitoring and diagnosis of postoperative complications following of third molar surgical removal.

Lactate dehydrogenase (LDH, EC 1.1.1.27), aspartate aminotransferase (AST, EC 2.6.1.1), alanine aminotransferase (ALT, EC 2.6.1.2), acid phosphatase (ACP, EC 3.1.3.2), tartrate-resistant acid phosphatase (TRAP; EC 3.1.3.2), and alkaline phosphatase (ALP, EC 3.1.3.1) are biomarkers of cellular damage and inflammation in saliva. The increased activity of these enzymes in saliva may be due to the destructive process of alveolar bone and the degradation of advanced periodontal disease $e^{6,7}$. Despite these facts, there have been no investigations of the alterations of these enzymes during the early stages of post-tooth extraction wound healing.

Oxidative stress is a result of a physiological imbalance between the production of reactive oxygen species (ROS) and their deactivation by enzymatic (catalase, superoxide dismutase, and glutathione peroxidase) and non-enzymatic (uric acid, vitamins E and C) antioxidant systems ${ }^{8}$. Antioxidants protect against endogenously formed free radicals and are present in all tissues and body fluids, including saliva. Nutrition, trauma, stress, and immune disturbance are some factors that contribute to disturbances of the oxidant/antioxidant balance of organisms. An excess of production of ROS has been correlated with several oral diseases. Saliva constitutes a first-line defence against oxidative stress and has protective effects against microorganisms, toxins, and oxidants. Uric acid (UA) is one of the most important non-enzymatic antioxidant and contributes approximately $70 \%$ of the salivary total antioxidant capacity (TAC) ${ }^{9}$. Salivary UA and TAC can be used as a biomarker to evaluate the health of periodontium $^{10,11}$. In these situation, salivary thiobarbituric reacting substances (TBARS) has been used as a biomarker for the measurement of oxidative damage $^{12}$. Although previous studies have reported that tooth extraction can trigger an increase of oxidative stress in the plasma ${ }^{13}$, it is still unknown if similar changes occur in saliva.

Unlike other oral dysfunctions and pathologic condition, in which monitoring salivary biomarkers is central to analyse of symptoms, quality of life and the successful treatment of patients, the changes in this fluid after the surgical removal of impacted lower third molars are not yet investigated. The present study was proposed in this context. Our hypothesis was that biomarkers of cellular damage and oxidative stress parameters are increased in saliva following surgical removal of lower third molars at time dependent manner.

\section{MATERIAL AND METHOD}

\section{- Patients}

Patients requiring impacted third molar surgical removal were initially considered for inclusion. Each patient underwent clinical and radiographic studies to ensure that the surgery was as simple as possible. To standardize the duration and difficulty of each operation, the Winter's Classification was used to classify the position of the impacted third molar relative to the long axis of the second molar. The final study included 8 men (18-26 years) and 9 women (20-26 years).

None of the volunteers had a history of chronic somatic illnesses such as autoimmune diseases, diabetes, cancer, metabolic disturbances, or obesity; none had a history of neurological or psychiatric disorders or alcohol abuse; and all were drug-free. In addition, participants had to be free of fever and/or cold, non-smokers, and have good oral hygiene; participants with gingival and periodontal inflammation were excluded. The research protocol was approved by the Human Ethics Committee on Research with Human Beings of the School of Dentistry, Araçatuba, São Paulo State University UNESP (permission no. CAAE 44625815.8.0000.5420) in accordance with ethical principles of the World Medical Association Declaration. All participants were requested to provide informed consent following a detailed explanation of the study.

- Surgical procedure

The surgical removal took place at the Oral and Maxillofacial Clinic of the Department of Surgery and Integrated Clinic of the School of Dentistry, Araçatuba - UNESP. One postgraduate student in a Master's degree programme in Oral and 
Maxillofacial Surgery and Traumatology performed the procedures. One lower third molar was extracted per session. The first specimens of saliva were collected before the third molar was removed. In the preoperative period, the patient used $10 \mathrm{~mL}$ of mouthwash with $0.12 \%$ chlorhexidine digluconate for $30 \mathrm{~s}$. Afterward, the patient received local anaesthesia (mepivacaine 2\%, epinephrine 1:100,000). A relaxing incision was made in the vestibular region of the second lower molar with a no. 15 blade and the total flap was detached with a Molt no. 9. Due to the position and localization of the third molar, all cases required an osteotomy, which was performed using a high-speed drill (conical bit no. 702) under irrigation. Some cases required tooth sectioning. After molar surgical removal, the incision was closed with a simple suture with non-absorbable nylon 4-0 wire to facilitate soft tissue healing and avoid infection.

Nimesulide (100 mg every $12 \mathrm{~h}$ for 3 days) and amoxicillin (500 mg every $8 \mathrm{~h}$ for 5 days) were prescribed as anti-inflammatory agents during the postsurgical period. Dipyrone $(500 \mathrm{mg}$ every $8 \mathrm{~h}$ for 2 days) was prescribed only for pain. Each patient received an explanation of hygiene techniques and recommendations for the postoperative period. All the participants were requested to rinse their mouth with $15 \mathrm{~mL}$ of $0.2 \%$ chlorhexidine twice a day for 1 week postoperatively. Patients with postoperative complications such as suture dehiscence, paraesthesia, alveolitis, or infection were excluded from the study.

\section{- Collection, processing, and storage of saliva samples}

As mentioned above, saliva samples were collected at three different time-points: before surgery and 1 day and 1 week after. Participants were asked to refrain from eating, drinking and oral hygiene procedures for at least 1-hour prior to saliva collection. Unstimulated whole expectorated saliva (5 $\mathrm{mL}$ ) was collected from each subject between 8 and 10 a.m., considering the circadian rhythm. Subjects rinsed their mouths with water $10 \mathrm{~min}$ prior to sampling. The first expectoration was discarded to eliminate food debris and unwanted substances capable of contaminating the sample, which might have caused analytical inaccuracy. The subsequent sample was then expectorated into sterile tubes kept on ice while the subject was seated in an upright position. The samples were kept on ice to minimize degradation of salivary proteins until further processing. Immediately after saliva collection, $\mathrm{pH}$ and buffer capacity (BC) were determined using a portable $\mathrm{pH}$ meter. The buffer capacity was measured by titration using $1 \mathrm{~mL}$ saliva and adding $0.2 \mathrm{~mL}$ of $0.01 \mathrm{~N} \mathrm{HCl}$. The addition of $\mathrm{HCl}$ was repeated, and the $\mathrm{pH}$ was recorded until a $\mathrm{pH}$ of 4.0 or less was reached ${ }^{14}$. To estimate the salivary flow rate (SFR), the saliva density was assumed to be $1 \mathrm{~g} / \mathrm{mL}$. The
SRF was calculated by dividing the sample volume $(\mathrm{mL})$ by the time (min) taken to produce it. Immediately after saliva collection, the saliva samples were centrifuged $\left(10,000 \times g\right.$ at $4^{\circ} \mathrm{C}$ for 10 $\mathrm{min})$ to remove cellular debris and minimize the turbidity of the saliva, which could negatively impact analytical accuracy. The supernatants were stored in aliquots at $-80^{\circ} \mathrm{C}$. Each aliquot was frozen and thawed only once.

\section{- Biochemical analysis of saliva}

Salivary haemoglobin $(\mathrm{Hb})$ levels were measured using hemoglobincyanide method, according to the manufacturer's instructions (Labtest Diagnostica S.A., MG, Brazil). Saliva samples with $0,1 \% \quad(1000 \mu \mathrm{g} / \mathrm{mL})$ blood contamination were excluded from analyses, since salivary biomarkers of oxidative stress can be altered by blood-contaminated saliva $^{15}$.

The salivary TP concentrations were determined using the modified Lowry method according to Hartree ${ }^{16}$ and were expressed in $\mathrm{g} / \mathrm{L}$. ACP activity was measured based on hydrolysis of the substrate $p$-nitrophenyl-phosphate $(p \mathrm{NPP})$ to $p$ nitrophenol $(p \mathrm{NP})$ at $\mathrm{pH}$ 5.0, which has an intense yellow colour at an alkaline $\mathrm{pH}$ (17). TRAP activity was measured by hydrolysis of $p \mathrm{NPP}$ to $p \mathrm{NP}$ at $\mathrm{pH}$ 5.8 in the presence of sodium tartrate and $p$-hydroxy mercury benzoate ${ }^{17}$; the latter acts by inhibiting acid phosphatases of low molecular weight. ALP activity was measured based on the enzyme's ability to catalyse the hydrolysis of $p \mathrm{NPP}$ to $p \mathrm{NP}$ at $\mathrm{pH} 9.4$ in the presence of magnesium chloride. In both determinations, the formation of $p \mathrm{NP}$ was determined spectrophotometrically by reading the absorbance at $405 \mathrm{~nm}$ using a molar extinction coefficient of 18,000 $\mathrm{M}^{-1} \mathrm{~cm}^{-1}$. Controls without enzyme were included in each assay to adjust for non-enzymatic hydrolysis of $p$ NPP. One unit of enzyme activity is defined as the amount of enzyme required to hydrolyse $1 \mu \mathrm{mol}$ of $p$ NPP per min at $37^{\circ} \mathrm{C}$. ACP, TRAP, and ALP activity was expressed as specific activity (U/g of total protein).

Salivary LDH, AST, and ALT activities were assessed using Labtest kits (Labtest Diagnostica S.A., MG, Brazil). AST activity was measured based on the transfer of an amino group from L-aspartate to 2$\alpha$-ketoglutarate with formation of oxaloacetate and Lglutamate; afterwards, oxaloacetate was reduced to malate by malate dehydrogenase with simultaneous oxidation of NADH to $\mathrm{NAD}^{+}$. ALT activity, similar to AST, was analysed using the method based on transfer of an amino group from L-alanine to 2- $\alpha$ ketoglutarate with formation of pyruvate, which was then reduced to L-lactate by LDH with simultaneous oxidation ${ }^{18}$ of $\mathrm{NADH}$ to $\mathrm{NAD}^{+}$. In both cases, the reduction of the absorbance at $340 \mathrm{~nm}$ in the sample was due to NADH oxidation, and was proportional to ALT and AST activity. LDH activity in the 
supernatant was determined by the enzymatic catalysis of the interconversion of pyruvate and lactate in the presence of NADH. The reduction of the absorbance at $340 \mathrm{~nm}$ due to NADH oxidation was proportional to the LDH activity in the sample ${ }^{19}$. The LDH, ALT, and AST activities were expressed as specific activity (U/g of total protein).

Salivary lipid peroxidation products were determined based on TBARS levels as previously described $^{20}$. Briefly, aliquots were mixed with $15 \%$ $(\mathrm{w} / \mathrm{v})$ trichloroacetic acid plus $0.375 \% \quad(\mathrm{w} / \mathrm{v})$ thiobarbituric acid and heated at $100{ }^{\circ} \mathrm{C}$ for $45 \mathrm{~min}$. Samples were cooled to room temperature, centrifuged at $1,000 \times g$ for $15 \mathrm{~min}$, and their absorbance at $535 \mathrm{~nm}$ was measured. The molar absorption coefficient was $1.56 \times 10^{5} \mathrm{M}^{-1} \mathrm{~cm}^{-1}$ and values were normalized to TP concentrations in each sample and expressed in $\mu \mathrm{mol} / \mathrm{g}$ of protein.

Salivary TAC was determined using the ferric reducing antioxidant power FRAP assay as previously described by Benzie and $\operatorname{Strain}^{21}$, based on the reduction of $\mathrm{Fe}^{3+}$ to $\mathrm{Fe}^{2+}$, which is chelated by 2,4,6-tri(2-pyridyl)-s-triazine (TPTZ) to form a $\mathrm{Fe}^{2+}$ TPTZ complex with a maximum absorbance at 593 $\mathrm{nm}$. The results were calculated using a standard curve constructed using different concentrations of $\mathrm{FeSO}_{4}$ solutions and values were normalized to TP concentrations in each sample and expressed in mmol $\mathrm{Fe}^{2+} / \mathrm{g}$ of total protein.

Salivary UA was evaluated using a Labtest kit (Labtest Diagnostica S.A., MG, Brazil) based on the enzymatic method of Trinder $^{22}$, per the manufacturer's instructions. Results were normalized to TP concentrations in each sample and expressed in $\mathrm{mg} / \mathrm{g}$ of total protein.

- Statistical methods

Data were expressed as mean + standard deviation. Parametric data were analysed by one-way ANOVA followed by the Tukey post-hoc test, while non-parametric data were analysed by Kruskal-Wallis test followed by the Dunn post-hoc test.

\section{RESULTS}

Table 1 expresses the average values of SRF, $\mathrm{pH}$, and volume of $\mathrm{HCl}$ used in $\mathrm{pH}$ titration, and the $\mathrm{TP}$ and $\mathrm{Hb}$ concentrations of whole saliva from participants before, 1 day, and 7 days after tooth surgical removal. No significant difference was observed in the values of SRF, $\mathrm{pH}, \mathrm{BC}$ and $\mathrm{TP}$ concentration before and after oral surgery. We found a significant increase $(p<0.01)$ in salivary $\mathrm{Hb}$ concentration on the first postoperative day; it returned to the initial value 7 days after surgery, possibly reflecting surgical wound haemorrhage.

Significantly higher salivary-specific activities of ACP $(p<0.05)$, TRAP $(p<0.001)$, ALP $(p<0.05)$, ALT $(p<0.01)$, AST $(p<0.0001)$, and LDH $(p<0.01)$ were observed after 1 day compared to pre-surgical values (Figures 1 and 2). When presurgical values were compared to values 7 days postsurgery, most values had returned to near baseline. The exception was AST, which remained high ( $p$ $<0.01$ ) compared to before surgery (Figure 2B).

Salivary TBARS, a biomarker of lipid oxidative damage, was significantly higher 1 day after oral surgery compared with the basal value ( $p<$ 0.05 ) (Figure 3A). At 7 days post-surgery, the salivary TBARS concentration approached presurgical values. In turn, the salivary UA concentration $(p<0.0001)$ and TAC $(p<0.001)$ were significantly decreased on the first day post-surgery compared to pre-surgery (Figure $3 \mathrm{~B}$ and C). At 7 days after the procedure, the UA and TAC values had returned to near baseline.

Table 1. SFR, $\mathrm{pH}$, and volume of acid $(0.01 \mathrm{~N} \mathrm{HCl})$ used to determine the $\mathrm{pH}$ range, $\mathrm{TP}$, and $\mathrm{Hb}$ concentration of whole saliva samples

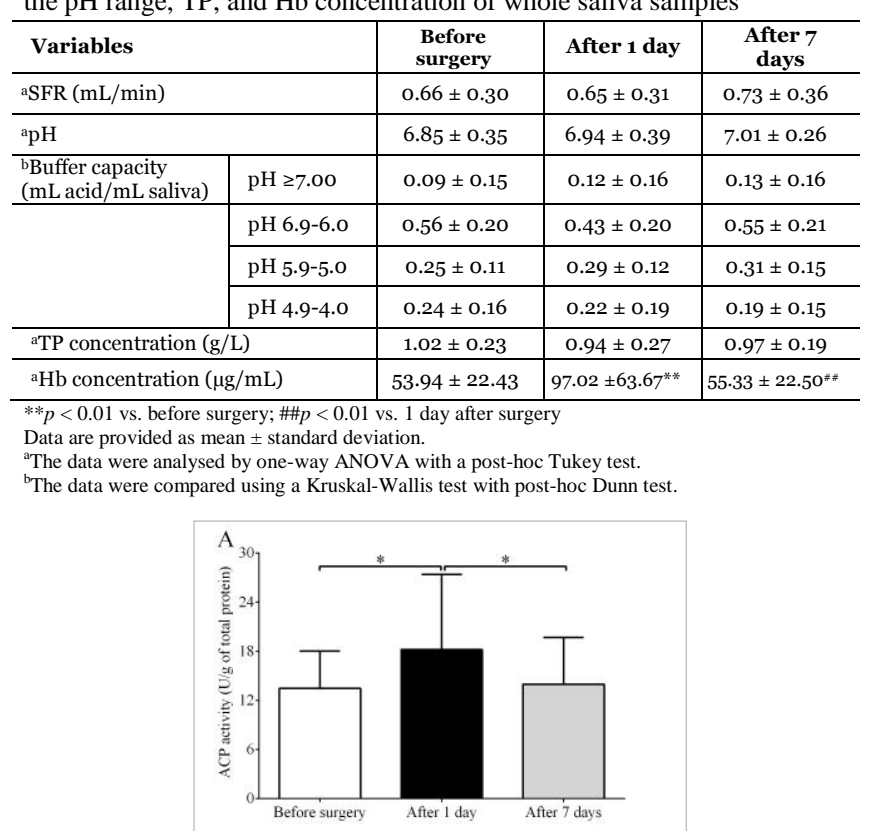
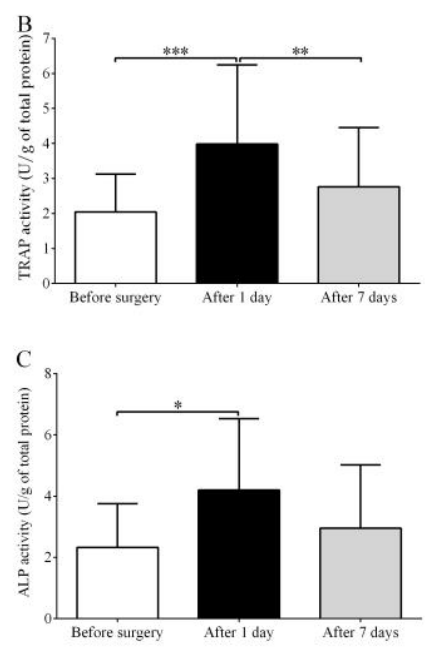

Figure 1: Activities of salivary acid phosphatase (ACP), tartrate-resistant acid phosphatase (TRAP), and alkaline phosphatase (ALP) throughout the perioperative period (before to 7 days after surgery). The data are expressed as mean + standard deviation. Data were analysed using a one-way ANOVA followed by a post-hoc Tukey test $\left({ }^{*} p<0.05\right.$; ** $p<0.01$; *** $p<0.001$; ***** $p<0.0001)$ 

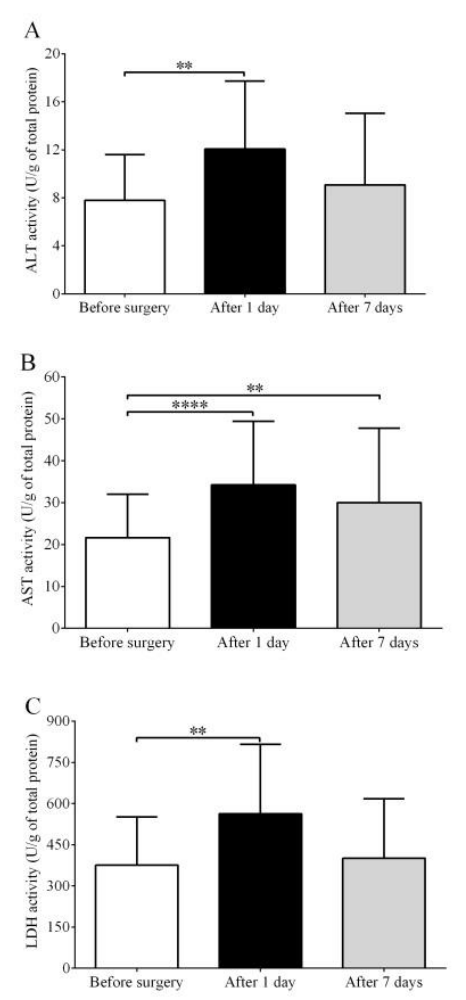

Figure 2: Activities of salivary alanine aminotransferase (ALT), aspartate aminotransferase (AST), and lactate dehydrogenase (LDH) throughout the perioperative period (before surgery to 7 days after surgery). The data are expressed as mean + standard deviation. Data were analysed using a one-way ANOVA followed by a post-hoc Tukey test $\left(* p<0.05 ;{ }^{* *} p<0.01 ; * * * p<\right.$ $0.001 ; * * * * p<0.0001)$.
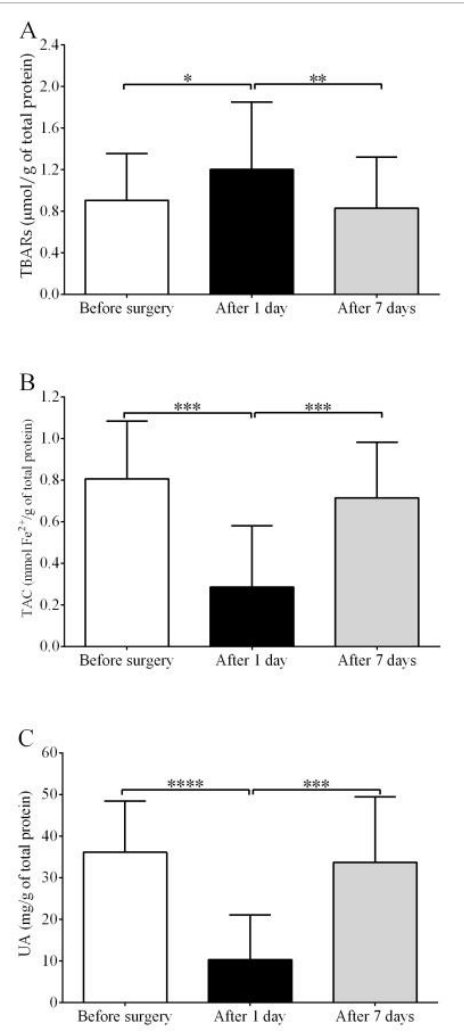

Figure 3: Levels of salivary thiobarbituric reacting substances (TBARS), total antioxidant capacity (TAC), and uric acid (UA) throughout the perioperative period (before surgery to 7 days after surgery). The data are expressed as mean + standard deviation. Data were analysed using a one-way ANOVA followed by a post-hoc Tukey test $(* p<0.05 ; * * p<0.01$; ***p $<0.001 ; * * * * p<$ $0.0001)$.

\section{DISCUSSION}

Considering that all patients received the same guidelines and postoperative medications, and none presented complications within the first week post-surgery, we consider that the salivary changes reflect normal events during early post-tooth extraction tissue repair. We did not detect significant variations between pre- and post-surgical values of $\mathrm{SRF}, \mathrm{pH}, \mathrm{BC}$ values, or TP concentration. In contrast, the salivary enzymes of tissue degradation were significantly higher 1 day after the procedure and had returned to baseline values after 7 days. In the same way, we observed a significant increase in lipid oxidative damage in the first postoperative day, but this parameter was similar to pre-surgical values after one week.

SRF, BC and $\mathrm{pH}$ can be important predictors in periodontium health status ${ }^{23,24}$. Although our findings do not show significant changes in these parameters within the first postoperative week, salivary $\mathrm{pH}$ is assumed to have a reverse correlation with third molar post- surgical removal pain ${ }^{25}$. The exclusion of volunteers had a history of chronic illnesses, poor oral hygiene and participants with gingival and periodontal inflammation can contribute to this results.

Salivary proteins play an important role in acquired pellicle formation and subsequent bacterial accumulation within the oral cavity. In addition, salivary proteins are involved in the inflammatory response, antimicrobial and immune defence, lubrication, buffering, and remineralisation capacities. Although salivary assays show that TP levels are higher in gingivitis and chronic periodontitis patients ${ }^{26}$, our data showed that injury from surgical removal of impacted lower third molars did not change this parameter, which corroborates a previous study of Gutierrez-Corrales et al. ${ }^{27}$ that also evaluated the effect of the acute inflammatory process occurring in the salivary TP after surgery.

The ability to reflect both oral and systemic health conditions has made saliva an attractive, easily collected, low-cost, and noninvasive clinical tool. However, in order to use saliva as a diagnostic body fluid, a sensitive and specific biomarker among the complicated composition of saliva must be specified for each case. In this context, salivary enzymes, oral microorganisms, polymorphonuclear leukocytes, and oral epithelial cells derived from gingival crevicular fluid have been highlighted as biomarkers, especially LDH, AST, ALT, ACP, TRAP, and ALP, which may be a consequence of the destructive process of the alveolar bone and the degradation of advanced stage tissues of periodontal disease. Our findings demonstrate for the first time that these enzymes also are involved in the early stages of post-tooth surgical removal wound healing. 
ALT, AST, LDH, ACP, and TRAP localized in the cytosol and/or cytoplasmic organelles, while ALP is associated with the plasma cell membrane. These enzymes are involved in various cell metabolic processes, and they are mostly present in the cells of hard and soft tissues. Increased activities of these enzymes in saliva are considered to be biomarkers of cellular damage and inflammation. After the surgical removal of impacted lower third molars, several potential sources of these enzymes emerge in the oral cavity, such as stromal, epithelial and inflammatory cells involved in the gingival flap and socket healing; blood clots within the alveolar socket; desquamated epithelial mucosa; and biofilms. The latter are accentuated due to the difficulty of oral hygiene after surgery. In addition, AST, ALT, and phosphatases may contribute to the intrinsic maturation of acquired enamel pellicle proteins ${ }^{28,29}$, the first step of oral biofilm formation and subsequent adhesion of opportunistic periodontal pathogens, which leads us to emphasize oral hygiene in the postoperative period to prevent infectious complications.

In normally healing wounds, ROS are required for defence against pathogens and act as messengers to stimulate processes associated with wound healing, including cell motility, cytokine action, and angiogenesis. However, an increased level of ROS may overlap the positive effects and cause additional tissue damage ${ }^{30}$. Previous studies have also reported that tooth extraction can trigger an increase of oxidative stress in the plasma ${ }^{13}$; however, there are no published reports related to salivary oxidative stress interactions after tooth extraction. To our knowledge, this is the first demonstration that the peak salivary oxidative stress response occurs between the immediate postoperative period and 24 hours after tooth surgical removal, as evidenced by the increased salivary TBARS and reduction of TAC levels. Seven days after surgery, TBARS levels had returned to near pre-surgical levels. This could be explained by the neutralizing action and subsequent restoration of antioxidant defence non-enzymatic, especially UA concentration, and/or reduction of free radical generation during wound healing and regeneration of gingival tissue surrounding the alveolar bone. This finding suggests a perspective for assessing whether complementary antioxidant therapies can benefit the repair process after tooth surgical removal.

The present data must be interpreted considering the following methodological limitations. First, small sample size was the main limitation of this study. Secondly, the results were not correlated with the parameters of the acute inflammatory process that occurred after surgery. Future researchers could consider whether the results obtained in the present study remain when using antiseptic mouth rinse after surgery in patients with pre-existing conditions to oral surgery, such as poor oral hygiene, gingivitis, or periodontitis, smokers, diabetes and hypertension and/or if the results are associated with inflammatory responses to surgery such as swelling and pain.

Our results confirm this hypothesis with significant increase of the salivary enzymes of the tissue degradation and lipid damage oxidation, and decreased the TAC in the early postoperative period after surgical removal of lower third molar from healthy patient and without postoperative complications. Considering these issues, our data open new perspectives of a possible use of these parameters as biomarkers for screening and monitoring of patients vulnerable to the development of postoperative complications.

\section{ACKNOWLEDGMENTS}

We thank the participants for their cooperation. The scientific initiation project was approved by São Paulo State University - UNESP (ICSB/PROPe/UNESP $\mathrm{N}^{\circ} 36151$ and PIBIC ENSINO MÉDIO/CNPq N 3752).

\section{REFERENCES}

1. Majid OW, Mahmood WK. Effect of submucosal and intramuscular dexamethasone on postoperative sequelae after third molar surgery: comparative study. Br J Oral Maxillofac Surg. 2011;49(8):647-52.

2. Larjava H. Oral wound healing : cell biology and clinical management. Oxford: Wiley-Blackwell; 2012. XVI, 408 p.p

3. Mohn CE, Steimetz T, Surkin PN, FernandezSolari J, Elverdin JC, Guglielmotti MB. Effects of saliva on early post-tooth extraction tissue repair in rats. Wound Repair Regen. 2015;23(2):241-50.

4. Ozmeric N, Mollaoglu N, Elgun S, Devrim E. Impact of chlorhexidine mouth rinse use on postextraction infection via nitric oxide pathway. Inflamm Res. 2010;59(6):437-41.

5. Dos Santos DR, Souza RO, Dias LB, Ribas TB, de Oliveira LCF, Sumida DH et al. The effects of storage time and temperature on the stability of salivary phosphatases, transaminases and dehydrogenase. Arch Oral Biol. 2018;85:160-65.

6. Dabra S, China K, Kaushik A. Salivary enzymes as diagnostic markers for detection of gingival/periodontal disease and their correlation with the severity of the disease. J Indian Soc Periodontol. 2012;16(3):358-64.

7. Cesco Rde T, Ito IY, de Albuquerque RF Jr. Levels of aspartate aminotransferase (AST) in saliva of patients with different periodontal conditions. J Clin Periodontol. 2003;30(8):752-55.

8. Cunha-Correia AS, Hernandes Neto A, Pereira AF, Aguiar SM, Nakamune AC. Enteral nutrition feeding alters antioxidant activity in unstimulated whole saliva composition of patients with 
neurological disorders. Res Dev Disabil. 2014;35(6):1209-15.

9. Nagler RM, Klein I, Zarzhevsky N, Drigues N, Reznick AZ. Characterization of the differentiated antioxidant profile of human saliva. Free Radic Biol Med. 2002;32(3):268-77.

10. Miricescu D, Totan A, Calenic B, Mocanu B, Didilescu A, Mohora $M$ et al. Salivary biomarkers: relationship between oxidative stress and alveolar bone loss in chronic periodontitis. Acta Odontol Scand. 2014;72(1):42-7.

11.Bansal N, Gupta ND, Bey A, Sharma VK, Gupta $\mathrm{N}$, Trivedi H. Impact of nonsurgical periodontal therapy on total antioxidant capacity in chronic periodontitis patients. J Indian Soc Periodontol. 2017;21(4):291-95.

12.Wang Y, Andrukhov O, Rausch-Fan X. Oxidative stress and antioxidant system in periodontitis. Front Physiol. 2017;8:910.

13. Cutando A, Arana C, Gomez-Moreno G, Escames G, Lopez A, Ferrera MJ et al. Local application of melatonin into alveolar sockets of beagle dogs reduces tooth removal-induced oxidative stress. J Periodontol. 2007;78(3):576-83.

14.Bassoukou IH, Nicolau J, dos Santos MT. Saliva flow rate, buffer capacity, and $\mathrm{pH}$ of autistic individuals. Clin Oral Investig. 2009;13(1):23-7.

15.Kamodyova N, Banasova L, Jansakova K, Koborova I, Tothova L, Stanko P et al. Blood contamination in saliva: impact on the measurement of salivary oxidative stress markers. Dis Markers. 2015;2015:479251.

16. Hartree EF. Determination of protein: a modification of the Lowry method that gives a linear photometric response. Anal Biochem. 1972;48(2):422-27.

17. Granjeiro JM, Taga EM, Aoyama H. Purification and characterization of a low-molecular-weight bovine kidney acid phosphatase. An Acad Bras Cienc. 1997;69(4):451-60.

18. Henry RJ, Chiamori N, Golub OJ, Berkman S. Revised spectrophotometric methods for the determination of glutamic-oxalacetic transaminase, glutamic-pyruvic transaminase, and lactic acid dehydrogenase. Tech Bull Regist Med Technol 1960;30:149-66.

19.Huijgen HJ, Sanders GT, Koster RW, Vreeken J, Bossuyt PM. The clinical value of lactate dehydrogenase in serum: a quantitative review. Eur J Clin Chem Clin Biochem. 1997;35(8):569-77.

20.Buege JA, Aust SD. Microsomal lipid peroxidation. Methods Enzymol. 1978;52:302-10.

21.Benzie IF, Strain JJ. The ferric reducing ability of plasma (FRAP) as a measure of "antioxidant power": the FRAP assay. Anal Biochem. 1996;239(1):70-6.
22. Trivedi RC, Rebar L, Berta E, Stong L. New enzymatic method for serum uric acid at $500 \mathrm{~nm}$. Clin Chem. 1978;24(11):1908-11.

23. Shaila M, Pai GP, Shetty P. Salivary protein concentration, flow rate, buffer capacity and $\mathrm{pH}$ estimation: A comparative study among young and elderly subjects, both normal and with gingivitis and periodontitis. J Indian Soc Periodontol. 2013;17(1):42-6.

24.Hosseini-Yekani A, Nadjarzadeh A, Vossoughi M, Reza JZ, Golkari A. Relationship between physicochemical properties of saliva and dental caries and periodontal status among female teachers living in Central Iran. J Int Soc Prevent Community Dent. 2018;8(1):48-55.

25.Jafari SM, Motamedi MH, Jafari M, Tabeshfar S, Jafari M, Naghizadeh MM. Impacted lower third molars: Can preoperative salivary $\mathrm{pH}$ influence postoperative pain? Natl J Maxillofac Surg. 2010;1(2):123-26.

26. Kejriwal S, Bhandary R, Thomas B, Kumari S. Estimation of levels of salivary mucin, amylase and total protein in gingivitis and chronic periodontitis patients. J Clin Diagn Res. 2014;8(10):ZC56-60.

27.Gutierrez-Corrales A, Campano-Cuevas E, Castillo-Dali G, Serrera-Figallo MA, TorresLagares D, Gutierrez-Perez JL. Relationship between salivary biomarkers and postoperative swelling after the extraction of impacted lower third molars. Int $\mathbf{J}$ Oral Maxillofac Surg. 2017;46(2):243-49.

28.Hannig C, Spitzmuller B, Hannig M. Transaminases in the acquired pellicle. Arch Oral Biol. 2009;54(5):445-48.

29.Hannig C, Spitzmuller B, Miller M, Hellwig E, Hannig M. Intrinsic enzymatic crosslinking and maturation of the in situ pellicle. Arch Oral Biol. 2008;53(5):416-22.

30. Rodriguez PG, Felix FN, Woodley DT, Shim EK. The role of oxygen in wound healing: a review of the literature. Dermatol Surg. 2008;34(9):1159-69.

\section{CONFLICTS OF INTERESTS}

The authors declare no conflicts of interests.

\section{CORRESPONDING AUTHOR}

\section{Antonio Hernandes Chaves Neto}

antonio.hernandes@unesp.br 